\title{
ISOLATION OF MUCORALES FROM PROCESSED MAIZE (ZEA MAYS L.) AND SCREENING FOR PROTEASE ACTIVITY
}

\author{
André Luiz Cabral Monteiro de Azevedo Santiago*; Cristina Maria de Souza Motta \\ Departamento de Micologia, Centro de Ciências Biológicas, Universidade Federal de Pernambuco, Recife, PE, Brasil \\ Submitted: September 12, 2007; Returned to authors for corrections: July 09, 2007; Approved: October 22, 2008.

\section{SHORT COMMUNICATION}

\begin{abstract}
Mucorales were isolated from maize flour, corn meal and cooked cornflakes using surface and depth plate methods. Rhizopus oryzae, Circinella muscae, Mucor subtilissimus, Mucor hiemalis f. hiemalis, Syncephalastrum racemosum, Rhizopus microsporus var. chinensis and Absidia cylindrospora showed protease activity.
\end{abstract}

Key-words: Zygomycetes, food, contamination, isolation

Mucorales are ubiquitous, morphologically simple terrestrial fungi that belong to the Zygomycetes. These molds are widespread in nature, and have been already isolated from soil, decaying vegetables, fruits and seeds (22). Some species of Mucorales are well-known as food contaminants, thus providing an important source of information concerning the hygiene condition of food deposits, imperfection on the storage process, extreme contamination of grain feedstock and presence of mycotoxins in substrata $(6,29)$.

Proteases account for approximately $60 \%$ of all enzyme sales (14). The major uses of free proteases occur in dry cleaning, detergents, meat processing, cheese making, silver recovery from photographic film, production of digestive and certain medical treatments of inflammation and virulent wounds (19). Several studies report the efficient kinds of protease biosynthesis by Rhizopus microsporus var. rhizopodiformis (3), Mucor circinelloides (30), R. oryzae (4) and Syncephalastrum racemosum (9), confirming the real potential of Mucorales in producing this enzyme.

The aims of this work were to isolate and identify Mucorales from maize flour, corn meal and cooked cornflakes and to characterize the species according to the presence or not of protease activity.

\section{Isolation and identification of Mucorales}

Processed products derived from maize, such as maize flour, corn meal and cooked cornflakes, and commercially available in Recife, Pernambuco, Brazil were used as substrata. Three different packages showing different packing dates were analyzed and discarded after the analysis.

Surface and depth plate methods were used for the isolation, following Silva et al. (27). In the former, 1:10, 1:100 and 1:1000 dilutions were performed. From each of these three dilutions, $0,1 \mathrm{~mL}$ was transferred to different sets of Petri dishes containing dichloran rose bengal chloramphenicol agar medium (DRBC) (15) and Sabouraud rose bengal chloramphenicol agar medium (SRBC) (17). Dilutions were the same for the surface and depth plate methods, but in the last method $1 \mathrm{~mL}$ from each resulting suspension was inoculated in empty sterilized Petri dishes. After that, $15 \mathrm{~mL}$ of DRBC and SRBC media cooled at $45^{\circ} \mathrm{C}$ were added to each Petri dish and put into motion, with soft circular movements. Colony growth was observed during 72 hours at room temperature $\left(28^{\circ} \mathrm{C} \pm 2^{\circ} \mathrm{C}\right)$. The inoculations to each medium and each dilution were done in triplicate.

Identification of Mucorales was carried out according to Benny (5), Hesseltine \& Fennel (10), Hesseltine \& Hellis (11), Hesseltine \& Hellis (12,13), Schipper (24), Schipper (25) and Schipper (26).

*Corresponding Author. Mailing address: Universidade Federal de Pernambuco, Departamento de Micologia, Av. Prof. Nelson Chaves s/n, Cidade Universitária, CEP 50670-420, Recife, PE, Brasil. Tel.: (81) 2126-8478. E-mail: andrelcabral@msn.com 


\section{Protease activity}

Fragments of grown cultures (7 days) were transferred to the center of Petri dishes containing casein media (17). The dishes in triplicate were kept at room temperature $\left(\mathrm{TA} 28^{\circ} \mathrm{C} \pm\right.$ $1^{\circ} \mathrm{C}$ ) for 7 days. In order to confirm the presence of a true proteolytic activity, an acid solution of mercury chloride was added to each plate. Protease production was certificated by the formation of a transparent halo $(17,23)$.

A total of 86 specimens representing 13 species of Mucorales were identified (Table 1). The highest number of $\mathrm{CFU} / \mathrm{g}$ was observed in Mycocladus corymbifer followed by R. oryzae and Mycocladus ramosus. Only $R$. oryzae was isolated from three different products. Among these three substrats, corn meal showed the highest number of species (12) and also CFU/g (59) followed by maize flour ( 3 species and $10 \mathrm{CFU} / \mathrm{g}$ ) and cooked cornflakes ( 2 species and $17 \mathrm{CFU} / \mathrm{g}$ ), corresponding to $68.60 \%$, $11.63 \%$ and $19.77 \%$, respectively. The isolation of Mucorales from maize products has been reported by several authors. As also observed in this manuscript, Rhizopus oryzae (21), Rhizopus sp. and Cunninghamella sp. (2) were isolated from corn meal. Absidia cylindrospora (21) and was isolated from maize flour. Rhizopus sp., Syncephalastrum sp., Absidia sp. and Mucor sp. (7), were isolated from maize foods in general. According to Banwart (4) and Sinha \& Sinha (28) Mucor sp. and Rhizopus sp. are common contaminants in places where products are stored, supporting the results described on this paper.
The presence of Mucorales in the studied products and the differences in the number of CFU/g among the three substrata are probably consequences of maize contamination in the field or during the harvest, processing, transporting, packaging, storage and also the low quality of grain feedstock $(18,28)$. The contamination of stocked maize grains can be caused by high humidity and temperature levels, inappropriate sanitary conditions, high level of fungi inoculation and exposition of grains to insects and mites $(8,19,28)$.

Absidia cylindrospora, Circinella muscae, Mucor hiemalis f. hiemalis, M. subtilissimus, Rhizopus microsporus var. chinensis, $R$. oryzae and Syncephalastrum racemosum showed positive protease activity. Their halo reached up to $9 \mathrm{~cm}$ (total diameter of Petri plate) after 7 days of incubation.

Protease activity in Mucoralean fungi has also been reported by several authors in the past years for $R$. oryzae (16), R. chinensis (31), S. racemosum (9), Mucor hiemalis f. hiemalis, $M$. hiemalis f. luteus, M. subtilissimus (2), in accordance with the results obtained in this research.

The results of the present study showed that several species of Mucorales are able to infect food products derived from maize. The great majority of the isolated Mucorales species are reported here for the first time on these substrata. The detection of protease activity indicates that those species of Mucorales may be able to produce this enzyme. However, specific studies should be carried out in order to verify the real potential of

Table 1. Number of Mucorales (CFU/g) isolated from corn meal, cooked cornflakes, and maize flour using surface and depth plate methods.

\begin{tabular}{|c|c|c|c|c|c|c|c|c|c|c|}
\hline \multirow[t]{2}{*}{ Species/substrate } & \multicolumn{3}{|c|}{ Corn meal } & \multicolumn{3}{|c|}{$\begin{array}{l}\text { Cooked } \\
\text { cornflakes }\end{array}$} & \multicolumn{3}{|c|}{$\begin{array}{c}\text { Maize } \\
\text { flour }\end{array}$} & \multirow[t]{2}{*}{ Total } \\
\hline & I & II & III & I & II & III & $\mathrm{I}$ & II & III & \\
\hline Absidia cylindrospora Hagem & 0 & 0 & 3 & 0 & 0 & 0 & 0 & 2 & 5 & 10 \\
\hline Mycocladus corymbifer (Cohn) Váñová & 17 & 1 & 1 & 0 & 0 & 0 & 0 & 1 & 0 & 20 \\
\hline M. hyalospora (Saito) J. H. Mirza & 1 & 3 & 0 & 0 & 0 & 0 & 0 & 0 & 0 & 4 \\
\hline M. ramosus (Zopf) Váñová & 7 & 0 & 11 & 0 & 0 & 0 & 0 & 0 & 0 & 18 \\
\hline Circinella muscae (Sorokin) Berl. \& De Toni & 0 & 0 & 1 & 0 & 0 & 0 & 0 & 0 & 0 & 1 \\
\hline Mucor amphibiorum Shipper & 1 & 0 & 0 & 0 & 0 & 0 & 0 & 0 & 0 & 1 \\
\hline M. subtilissimus Oudem & 0 & 2 & 2 & 0 & 0 & 0 & 0 & 0 & 0 & 4 \\
\hline M. hiemalis f. hiemalis Wehmer & 1 & 0 & 2 & 0 & 0 & 0 & 0 & 0 & 0 & 3 \\
\hline M. hiemalis f. luteus (Linnem.) Schipper & 1 & 0 & 0 & 0 & 0 & 0 & 0 & 0 & 0 & 1 \\
\hline Syncephalastrum racemosum Cohn ex J. Schröt & 1 & 0 & 0 & 0 & 0 & 0 & 0 & 0 & 0 & 1 \\
\hline Rhizopus microsporus var. chinensis (Saito) Schipper \& Stalpers & 0 & 0 & 0 & 3 & 0 & 0 & 0 & 0 & 0 & 3 \\
\hline R. microsporus var. rhizopodiformis (Cohn) Schipper \& Stalpers & 1 & 0 & 0 & 0 & 0 & 0 & 0 & 0 & 0 & 1 \\
\hline R. oryzae Went. \& Prinsen Geerl & 0 & 0 & 3 & 3 & 0 & 11 & 0 & 0 & 2 & 19 \\
\hline Total & 30 & 6 & 23 & 6 & 0 & 11 & 0 & 3 & 7 & 86 \\
\hline Percentage & \multicolumn{3}{|c|}{$68.60 \%$} & \multicolumn{3}{|c|}{$19.77 \%$} & \multicolumn{3}{|c|}{$11.63 \%$} & \\
\hline
\end{tabular}

I, II, III = different packages from each corn product (substrate). 
enzyme production. This is the first report of proteolytic activity for Absidia cylindrospora and Circinella muscae.

\section{ACKNOWLEDGEMENTS}

This study was supported by a Masters scholarship to the first author from the Conselho Nacional de Desenvolvimento Científico e Tecnológico (CNPq). We warmly thank Dr. Maria Auxiliadora de Queiroz Cavalcanti and Dr. Sandra Farto Botelho Trufem for taxonomic support, and Dr. Tatiana Gibertoni and Dr. Marcela Cáceres for English language review.

\section{RESUMO}

\section{Isolamento de Mucorales de milho processado (Zea mays L.) e seleção quanto à atividade proteásica}

Mucorales foram isolados da farinha de milho, fubá e flocos de milho pré-cozidos pelos métodos de plaqueamento em superfície e em profundidade. Rhizopus oryzae, Circinella muscae, Mucor subtilissimus, Mucor hiemalis f. hiemalis, Syncephalastrum racemosum, Rhizopus microsporus var. chinensis e Absidia cylindrospora exibiram atividade proteásica.

Palavras-chave: Zygomycetes, alimento, contaminação, isolamento

\section{REFERENCES}

1. Alhadas, R.V.; Stuart, R.M.; Beux, M.R.; Pimentel, I.C. (2004). Contagem de bolores e leveduras em fubá e identificação de gêneros potencialmente toxigênicos. Visão Acad., 5, 79-82.

2. Alves, M.H.; Trufem, S.F.B.; Milanez, A.I. (2002). Táxons de Mucor Fresen. (Zygomycota) em fezes de herbívoros, Recife, PE, Brasil. Rev. Bras. Bot., 25, 147-160.

3. Andrade, V.S.; Sarubbo, L.A.; Fukushima, K.; Miyaji, M.; Nishimura, K.; Campos-Takaki, G.M. (2002). Production of extracellular proteases by Mucor circinelloides using D-glucose as carbon source/ substrate. Braz. J. Microbiol., 33, 106-110.

4. Banwart, G.J. (1981). Basic food microbiology. The AVI Publishing Company, Westport.

5. Benny, G.L. (1982). Zygomycetes. In: Parker, S.P. (Ed). Synopsis and Classification of Living Organisms. Mc Graw - Hill Book Co., New York, p. 184-195.

6. Farias, A.X.; Robbs, C.F.; Bittencourt, A.M.; Andersen, P.M.; Corrêa, T.B.S. (2000). Contaminação endógena por Aspergillus spp. em milho pós-colheita no Estado do Paraná. Pesq. Agropec. Bras., 35, 617-621.

7. Fennel, C.I.; Lillehoj, E.B.; Kwolek, W.F. (1975). Aspergillus flavus and other fungi associated with insect-damaged field corn, Cereal Chem., 52, 314-321.

8. Hagstrum, D.W.; Flinn, P.W. (1992). Integrated pest management of stored-grain insects. In: Sauer, D.B. (Ed). Storage of cereal grains and their products. American Association of Cereal Chemists, St. Paul, p. 535-562.

9. Heng-Chien, H.; Pyng-Fang, S.; Shih-Lu, W. (1998). Single-column purification of syncephapepsin - An aspartic proteinase from Syncephalastrum racemosum. Prot. Expr. Purific., 12, 399-403.

10. Hesseltine, C.W.; Fennel, D.I. (1995). The genus Circinella. Mycologia, 7, 193-211.

11. Hesseltine, C.W.; Hellis J.J. (1964). The genus Absidia: Gongronella and cylindrical-spored species of Absidia. Mycologia, 56, 571-601.

12. Hesseltine, C.W.; Hellis, J.J. (1966a). Species of Absidia with ovoid sporangiospores. I. Mycologia, 58, 761-785.

13. Hesseltine, C.W.; Hellis, J.J. (1966b). Species of Absidia with ovoid sporangiospores. II. Sabouraudia, 5, 59-77.

14. Ikasari L.; Mitchell D.A. (1996). Leaching and characterization of Rhizopus oligosporus acid protease from solid-state fermentation. Enzyme Microb. Tech., 19, 171-5.

15. King, A.D.; Hocking, A.D.; Pitt, J.I. (1979). Dichloran-rose bengal medium for enumeration and isolation of fungi from foods. Appl. Environm. Microbiol., 37, 959-964.

16. Kumar, S.; Sharma, N.S.; Saharan, M.R.; Singh, R. (2005). Extracellular acid protease from Rhizopus oryzae: purification and characterization. Process. Biochem., 40, 1701-1705.

17. Lacaz, C.S.; Porto, E.; Martins, J.E.C.M.; Heis-Vaccari, E.M.; Melo, N.T. (2002). Tratado de micologia médica Lacaz. Sarvier, São Paulo.

18. Márcia, B.A.; Lazzari, F.A. (1998). Monitoramento de fungos em milho em grão, grits e corn meal. Ciênc. Tecnol. Alimen., 18, 363367.

19. Miller, J.D. (1995). Fungi and mycotoxins in grain: implications for stored product research. J. stored prod. Res., 31, 1-16.

20. Nout, M.J.R.; Rombouts, F.M. (1990). A review: recent developments in tempe research. J. Appl. Bacteriol., 69, 609-633.

21. Ribeiro, S.A.L.; Cavalcanti, M.A.Q.; Fernandes, M.J.S.; Lima, D.M.M. (2003). Fungos filamentosos isolados de produtos derivados do milho comercializados em Recife, Pernambuco. Rev. Bras. Bot., 6, 223-229.

22. Ribes, J.A.; Vanover-Sams C.L.; Baker D.J. (2000). Zygomycetes in human disease. Clin. Microbiol. Rev. 13, 236-301.

23. Sarath, G.; De la Motte, R.S.; Wagner, F.W. (1989). Protease assay methods. In: Beynon, R.J. (Ed). Proteolytic enzymes: a practical approach. University Press, Oxford, p. 25-54.

24. Schipper, M.A.A. (1978). On certain species of Mucor with a key to all accepted species. Stud. Mycol., 25, 1-53.

25. Schipper, M.A.; Stalpers, J.A. (1983). Spore ornamentation and species concept in Syncephalastrum. Persoonia, 12, 81-85.

26. Schipper, M.A.A. (1984). A revision of the genus Rhizopus. I. The Rhizopus stolonifer-group and Rhizopus oryzae. Stud. Mycol., 25, 1-34.

27. Silva, N.; Junqueira, V.C.A.; Silveira, N.F.A. (2001). Manual de métodos de análise microbiológica de alimentos. $2^{\mathrm{a}}$ ed., Varella, São Paulo.

28. Sinha, K.K.; Sinha, A.K. (1991). Effect of Sitophilus oryzae infestation on Aspergillus flavus infection and aflatoxin contamination in stored wheat. J. Stor. Prod. Res., 27, 65-68.

29. Siqueira, R.S. (1995). Manual de tecnologia de alimentos. EMBRAPA-CTAA, Rio de Janeiro.

30. Spreer, A.; Rüchel, R.; Reichard, U. (2006). Characterization of an extracellular subtilisin protease of Rhizopus microsporus and evidence for its expression during invasive rhinoorbital mycosis. Med. Mycol., 44 (8), 723-731.

31. Swan, I.D.A. (1971). Crystallization and preliminary crystallographic data for the acid protease from Rhizopus chinensis. J. Molec. Biol., 60, 405-406. 